Re-examining Bhagwati hypothesis: the case of some selected countries in Sub-Saharan Africa

Muazu Ibrahim, Isaac Koomson, Olufemi Adewale Aluko, Eric Evans Osei Opoku

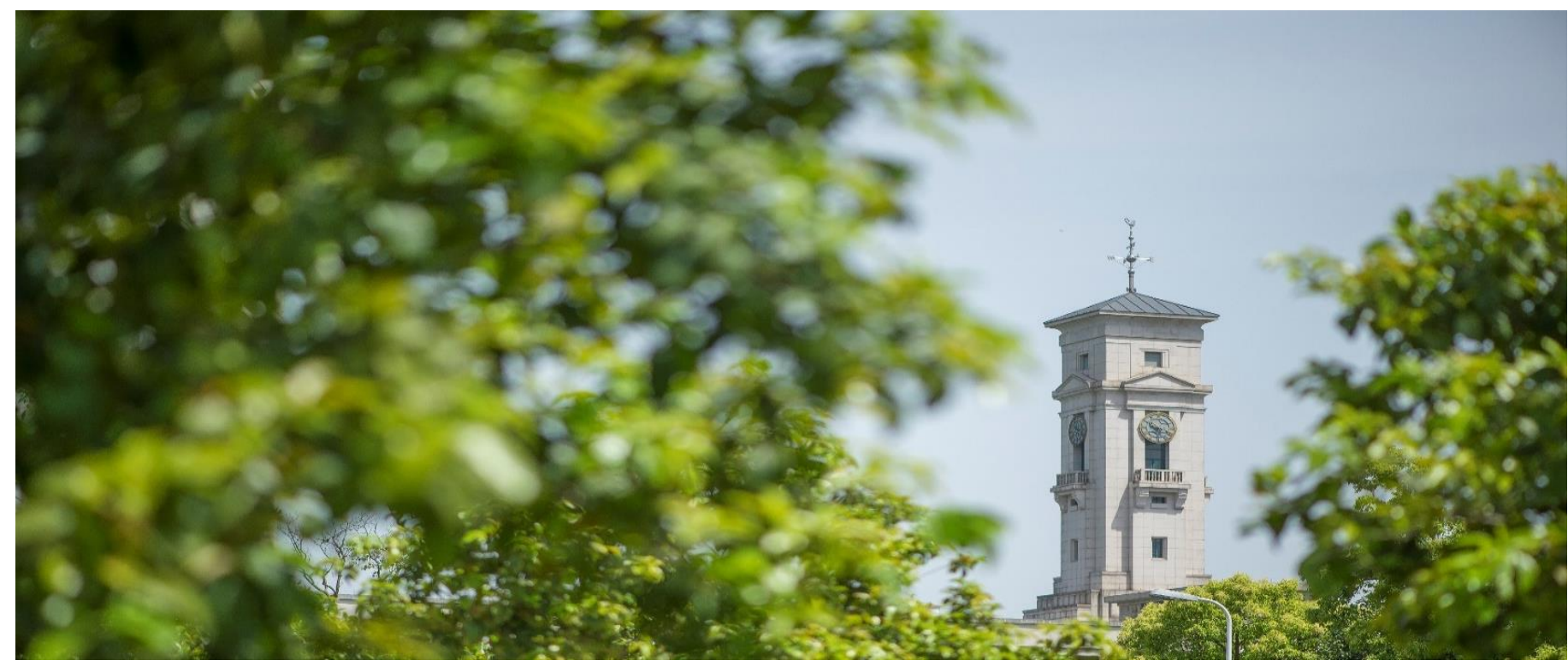


University of Nottingham Ningbo China, 199 Taikang East Road, Ningbo, 315100, Zhejiang, China.

First published 2021

This work is made available under the terms of the Creative Commons Attribution 4.0 International License:

http://creativecommons.org/licenses/by/4.0

The work is licenced to the University of Nottingham Ningbo China under the Global University Publication Licence:

https://www.nottingham.edu.cn/en/library/documents/research/global -university-publications-licence-2.0.pdf 


\title{
Re-examining Bhagwati hypothesis: The case of some selected countries in sub-Saharan Africa
}

\author{
${ }^{\mathrm{a}}$ Muazu Ibrahim $\quad{ }^{\mathrm{b}}$ Isaac Koomson $\quad{ }^{\mathrm{c}}$ Olufemi Adewale Aluko*dEric Evans Osei Opoku \\ ${ }^{a}$ School of Business and Law (SBL), Department of Banking and Finance \\ University for Development Studies, Wa, Upper West region, Ghana. \\ ${ }^{b}$ UNE Business School, University of New England, Armidale, NSW, Australia \\ ${ }^{c}$ Department of Finance, University of Ilorin, Kwara State, Nigeria. \\ ${ }^{\mathrm{d}}$ Nottingham University Business School, University of Nottingham Ningbo, China. \\ * Corresponding author's email: olufemiadewale6@ gmail.com
}

\begin{abstract}
Bhagwati hypothesis opines that the overall impact of foreign direct investment (FDI) on economic growth is conditioned on countries' level of integration with the international market. We test this hypothesis for some selected countries in sub-Saharan Africa (SSA). Does this hypothesis hold given our sample evidence? Yes! No! Maybe! We explain why. By invoking the sample splitting and threshold estimation technique, we find that the two measures of openness (trade openness and exports) mediate the FDI-economic growth relationship in three countries and this is an indication of complete Bhagwati hypothesis in these countries. Also, we find that, given the measure of openness, four countries exhibit incomplete Bhagwati hypothesis. Finally, we find no support for the Bhagwati hypothesis for most countries. Based on these findings, we argue that the validity of the Bhagwati hypothesis may be contingent on both country characteristics and the indicator of openness.
\end{abstract}

Keywords: FDI; Economic Growth; Trade Openness; Exports; Threshold

\subsection{Introduction}

Achieving high economic growth is the paramount objective of governments all over the world as it improves the standard of living of their citizens. Openness of the economy (to both trade and inflows of capital) is upheld as one of very important contributing factors of economic growth, particularly in developing countries. The World Bank, International Monetary Fund and World Trade Organization support the notion that openness is good for growth. The formation of the World Trade Organization and the Multilateral Investment Guarantee Agency (MIGA) are at the forefront of ensuring that fair rules apply on the playing grounds for the flows of goods, services and capital. MIGA is particularly interested in moderating capital inflows into developing countries, and its impact in Africa has been substantial (MIGA, 2015). Trade and foreign direct investment (FDI) inflows are largely argued in the literature to improve competitiveness of firms, lead to economies of scale, widen markets, increase the impact of positive spillovers among others (Zhang, 2001; Liu, Burridge, \& Sinclair, 2002; Liu, Shu \& Sinclair, 2009; Adams \& Opoku, 2015; Sakyi, Commodore \& Opoku, 2015; Iamsiraroj, 2016). ${ }^{1}$

${ }^{1}$ For recent determinants of FDI and trade openness in Africa, see Ibrahim et al. (2019) and Osei et al. (2019) respectively. 
Extant empirical studies on the impact of trade and FDI have been conducted especially following the liberalization of a greater number of African countries in the 1980s (see for example, Adams \& Opoku, 2015; Soumaré, 2015; Musila, \&Yiheyis, 2016; Iamsiraroj, 2016; Mahembe\& Odhiambo, 2016; Zahonogo, 2016; Zekarias, 2016; Acquah and Ibrahim, 2019; Bouchoucha and Yahyaoui, 2019). Most of the earlier studies focused on finding the separate impact of trade and FDI on economic growth. However, in the well cited works of Bhagwati $(1973,1978)$, he hypothesized that the overall impact of FDI on economic growth is conditioned on countries' level of integration with the international market. Though he subscribed to the potential effect of FDI on economic growth, he argued that the effect of FDI can only be actualized based on the how open an economy is to the rest of the world. This has come to be known in the literature as the Bhagwati hypothesis.

About two decades after the inception of the Bhagwati hypothesis, a number of studies started testing its efficacy. These studies have largely found validation for the hypothesis. For example, the Bhagwati hypothesis has been confirmed by Balasubramanyamet al. (1996) for 18 export promotion and 28 import substitution countries, Kohpaiboon (2003) for Thailand, Atiqueet al. (2004) for Pakistan, MakkiandSomwaru (2004) for 66 developing countries, Hsiao and Hsiao (2006) for 8 developing East and Southeast Asian economies, Hoang et al. (2010) for 61 provinces in Vietnam. In Africa, not much has been done in testing the Bhagwati hypothesis. Some of the remarkable studies that can be cited are Sakyi et al., (2015) who also find validation of the hypothesis using data from Ghana using the autoregressive distributed lag (ARDL) approach, and Sakyi and Egyir (2017) for 45 countries in Africa relying on the system generalized method of moments (GMM).

Though the Bhagwati hypothesis has been widely studied, most of these studies have examined the hypothesis by interacting FDI and openness in the growth equation where the conditional effects are evaluated at the mean, minimum and maximum value of trade (see for instance Sakyi et al., 2015; Sakyi \&Egyir, 2017). In terms of estimation approach, the existing studies have relied on linear approaches which do not reveal how FDI impacts on economic growth given an estimated threshold level of openness. Indeed, this study argues that, testing for the validity of the Bhagwati hypothesis goes beyond what the linear relationships show. More importantly, an appropriate form of testing the hypothesis entails examining how FDI drives countries' economic growth when countries' level of integration with the international market is below or above an estimated threshold of openness. In this endeavour, not only is the precise impact of FDI on growth at the different levels documented and the threshold value estimated, the confidence level of the threshold is unearthed. However, relying on the techniques are not instructive as they do not show the precise FDI-growth nexus when the link is mediated by the level of openness. In this study, we re-examine the Bhagwati hypothesis using a sample splitting technique that reveals the FDI-growth relationship when openness is either above or below an estimated threshold.

We contribute significantly to the literature in two ways. First, apart from unearthing the threshold level of openness where FDI-growth link may change effect, this study estimates the precise impact of FDI on economic growth when countries are below and above the threshold level of openness. Here, we are able to identify the regimes of openness where FDI inhibits or spurs growth. Second, relative to the earlier studies, we deviate from the use of panel data which does not consider the different heterogeneous characteristics of each country. More specifically, 
the study employs times series data for each country and by so doing, we are able to show how each country's level of international integration mediate the relationship between FDI and economic growth. We find evidence of the Bhagwati hypothesis in seven countries. However, the evidence of the Bhagwati hypothesis is complete (strong) in three countries only while it is incomplete (weak) in four countries. Similarly, we find that the Bhagwati hypothesis is absent in most of the countries considered for this study. Finally, we observe that, whether the level of openness mediates the relationship between FDI and economic growth depends on both the country characteristics and the indicator of openness.

The remainder of this study continues as follows. The next section elaborates on the methodology employed, section three presents and discusses the results and the last section concludes.

\subsection{Methodology}

\subsection{Data and empirical strategy}

We use data from 17 SSA countries. The choice of these countries and the time period as shown in Table 1 is based on data availability. Economic growth as the dependent variable is proxied by annual GDP growth rate. FDI is the regressor and measured as net FDI inflows as a percentage of GDP. We use two measures to denote countries' international market integration: (i) trade openness and (ii) exports as a percentage of GDP. Trade openness is taken as the ratio of the sum of countries' imports and exports to GDP while exports of goods and services represent the value of all goods and other market services provided to the rest of the world. This measure has been used in recent literature to denote countries' interaction with global markets (see Ibrahim and Sare, 2018; Ibrahim and Alagidede, 2017a,b; 2018; Opoku et al. 2019; Ibrahim, 2018; Aluko and Ibrahim, 2020a; Osei et al. 2019). We also include other standard controls of growth notably domestic capital proxied by gross fixed capital formation, labour and domestic credit as an indicator of financial sector development. All these variables are taken from the World Development Indicators (WDI) of the World Bank.

With regard to the empirical strategy, this study relies on Hansen's $(1996,2000)$ sample splitting approach which utilizes the least square estimation. ${ }^{2}$ Given the Bhagwati hypothesis, we set up equation (1) such that, the impact of FDI on economic growth is conditioned on countries' level of openness. We thus treat openness as the threshold variable with economic growth and FDI as the regressand and regressor respectively. In other words, we estimate the following equation:

$$
E C O_{i}=\left(\beta_{0}+\beta_{1} F D I_{i t}+\beta_{2} \operatorname{CON}_{i t}\right) d_{i}\left(q_{i} \leq \gamma\right)+\left(\beta_{0}+\beta_{1} F D I_{i t}+\beta_{2} \operatorname{CON}_{i t}\right) d_{i}\left(q_{i}>\gamma\right)+\varepsilon_{i}
$$

where $E C O_{i}$ represents economic growth in country $i$; $F D I_{i}$ is FDI in country $i$; $q_{i}$ is a vector of the threshold variables (trade openness and exports) that mediate the link between FDI and economic growth; $C O N_{i}$ is a vector of the control variables; $\gamma$ is the unknown threshold value of openness, while $d_{i}($.$) is the indicator function which is assigned the value of 1$ if the condition in the indicator function holds and 0 if otherwise; $\varepsilon_{i}$ is a noise term while $\beta_{i}$ are the parameters.

We estimate the equation while introducing the openness proxies at a time for cases where we find evidence of threshold. To the extent that $q_{i}$ is a continuous distribution, how FDI influences

\footnotetext{
${ }^{2}$ This approach has also been used recently by Alagidede et al. (2018) and Aluko and Ibrahim (2020b).
} 
economic growth depends on $\gamma$. We limit $\gamma$ to a bounded set $[\underline{\gamma}, \bar{\gamma}]=\alpha$ and the least squares estimators $(\hat{\beta}, \hat{\gamma})$ are determined using the concentration approach where the estimated $\hat{\gamma}$ is the value that minimizes sum of the squared residuals $\left[S S E_{n}(\gamma)\right]$ and can therefore be stated as:

$$
\hat{\gamma}=\underbrace{\operatorname{argmin}}_{\gamma \in \alpha} S S E_{n}(\gamma)
$$

where $\alpha_{n}=\alpha \bigcap\left\{g_{1}, g_{2}, \ldots \ldots \ldots, g_{n}\right\}$ while the slope estimators are estimated as $\hat{\beta}=\hat{\beta}(\hat{\gamma})$. Hansen (1996) proposes a Likelihood Ratio (LR) test which is a heteroskedasticity-consistent Lagrange Multiplier (LM) test to determine the statistical significance of $\hat{\gamma}$ :

$$
L R_{n}(\gamma)=n \frac{S S E_{n}(\gamma)-S S E_{n}(\hat{\gamma})}{S S E_{n}(\hat{\gamma})}
$$

In order to test for Bhagwati hypothesis, we first check for the existence of trade openness and exports thresholds for the relationship between FDI and economic growth. It is important to note that, the bootstrap procedure suggested by Hansen (1996) is relied on to ensure asymptotic distribution of the LR test statistic. Indeed, the consistency of $\gamma$ depends on where it lies within the confidence interval (c) which is asymptotic using the $L R_{n}(\gamma)$ set at $\hat{\alpha}=\left\{\gamma: L R_{n}(\gamma) \leq\right.$ $c\}$.Under the null hypothesis of no threshold effect, the threshold parameter is not identified and this makes the asymptotic distribution of the LR test statistic nonstandard. Here, the null hypothesis is rejected for large values of $L R_{n}\left(\gamma_{0}\right)$ in favour of the alternative hypothesis. By rejecting the null hypothesis, we find evidence of threshold confirming the Bhagwati hypothesis. Once the hypothesis is confirmed, our findings suggest that the link between FDI and economic growth is conditioned on the openness. Thus, we proceed to estimate the precise threshold values for our threshold variables as well as the impact of FDI on growth. We present the findings in the next section.

\subsection{Findings and discussions}

This section presents findings of the study where we begin with the test for threshold. Three possible outcomes are notable. First, there is a complete Bhagwati hypothesis if we reject the null hypothesis for the two different proxies of openness namely trade openness and exports. Second, there is incomplete Bhagwati hypothesis if we fail to reject the null hypothesis for either trade openness or exports. Third, there is no evidence Bhagwati hypothesis if we do not reject the hypothesis for the different measures of openness. Table 1 reports the results of the threshold tests. ${ }^{3}$ We find statistically significant threshold estimates for Botswana, Cameroon, Ghana, Mali, and South Africa using trade openness as the threshold variable, thus indicating that trade openness has a threshold effect in the relationship between FDI and economic growth in these countries. This finding suggests that the growth effect of FDI in these countries may be contingent on the extent to which the countries are open to trade. Turning to exports, Botswana, Equatorial Guinea, Ghana, Mali, and Senegal exhibit statistically significant threshold estimates and this informs that the impact of FDI on economic growth in these countries may be mediated by exports.

\footnotetext{
${ }^{3} \mathrm{We}$ do not provide the descriptive statistics of the variables for the countries but are available upon request from the authors. We however report confidence interval graphs for the existence of threshold in the appendix.
} 
Table 1: Testing for existence of threshold

\begin{tabular}{|c|c|c|c|c|c|}
\hline \multirow{2}{*}{ Countries } & \multirow{2}{*}{ Time period } & \multicolumn{2}{|c|}{$\begin{array}{l}\text { Trade openness as the threshold } \\
\text { variable }\end{array}$} & \multicolumn{2}{|c|}{ Exports as the threshold variable } \\
\hline & & $\begin{array}{l}\text { LM-test for no } \\
\text { threshold }\end{array}$ & $\begin{array}{l}\text { Bootstrap } p \text { - } \\
\text { value }\end{array}$ & $\begin{array}{l}\text { LM-test for no } \\
\text { threshold }\end{array}$ & $\begin{array}{l}\text { Bootstrap } p- \\
\text { value }\end{array}$ \\
\hline Benin & $1982-2018$ & 9.088 & 0.326 & 10.984 & 0.152 \\
\hline Botswana & $1976-2018$ & 17.008 & $0.000 * * *$ & 14.993 & $0.008 * * *$ \\
\hline Burkina Faso & $1979-2018$ & 9.776 & 0.376 & 11.704 & 0.153 \\
\hline Cameroon & $1977-2018$ & 18.554 & $0.000 * * *$ & 10.993 & 0.152 \\
\hline Cote d'Ivoire & $1975-2018$ & 8.626 & 0.5225 & 11.882 & 0.100 \\
\hline Congo, Dem. Rep. & $1970-2018$ & 8.581 & 0.663 & 9.840 & 0.429 \\
\hline Equatorial Guinea & $1985-2018$ & 6.694 & 0.876 & 12.811 & $0.029 * *$ \\
\hline Ghana & $1975-2018$ & 12.439 & $0.092 *$ & 13.382 & $0.046^{* *}$ \\
\hline Kenya & $1970-2018$ & 6.496 & 0.885 & 7.987 & 0.668 \\
\hline Malawi & $1973-2018$ & 8.402 & 0.697 & 10.495 & 0.222 \\
\hline Mali & $1971-2018$ & 12.204 & $0.095^{*}$ & 15.068 & $0.010^{* *}$ \\
\hline Mauritius & $1977-2018$ & 7.723 & 0.700 & 8.627 & 0.529 \\
\hline Nigeria & $1981-2018$ & 6.888 & 0.830 & 7.459 & 0.683 \\
\hline Senegal & $1970-2018$ & 8.257 & 0.772 & 13.660 & $0.066^{*}$ \\
\hline South Africa & $1970-2018$ & 13.509 & $0.050 *$ & 12.101 & 0.114 \\
\hline Tanzania & $1990-2018$ & 9.978 & 0.286 & 11.393 & 0.124 \\
\hline Togo & $1980-2018$ & 8.695 & 0.624 & 9.656 & 0.466 \\
\hline
\end{tabular}

Note: $*, * *$ and $* * *$ denote significance at $10 \%, 5 \%$ and $1 \%$ respectively. Number of bootstrap replications is 2,000 .

In Benin, Burkina Faso, Cote d'Ivoire, Democratic Republic of Congo, Kenya, Malawi, Mauritius, Nigeria, Tanzania, and Togo, we observe that there are no thresholds of trade openness and exports for the relationship between FDI and economic growth due to the absence of statistically significant threshold estimates for trade openness and exports. These findings suggest that possible discontinuities in the FDI-economic growth relationship in these countries cannot be attributed to variations in trade openness and exports. Overall, the results of the threshold tests reveal the possibility to test for Bhagwati hypothesis in only Botswana, Cameroon, Equatorial Guinea, Ghana, Mali, Senegal, and South Africa based on the sample splitting approach.

We proceed to testing for the validity of the Bhagwati hypothesis in Botswana, Cameroon, Equatorial Guinea, Ghana, Mali, Senegal, and South Africa by examining the impact of FDI on economic growth below and above the thresholds. A critical interrogation of Table 1 suggests the existence of complete Bhagwati hypothesis for three countries (Botswana, Ghana and Mali), and incomplete hypothesis for four countries (Cameroon, Equatorial Guinea, Senegal and South Africa). Thus, for these countries, whether FDI spurs or inhibits economic growth depends on whether the countries are operating below or above the estimated threshold value of openness. For the remaining countries, there is no evidence to support the Bhagwati hypothesis. Given this evidence, we proceed to empirically estimate the impact of FDI on growth for countries where 
either complete or incomplete Bhagwati hypothesis is found. Table 2 presents the results of the threshold estimation effects.

The global ordinary least squares (OLS) estimation results show that the linear relationship between FDI and economic growth is not statistically significant in all countries, implying that FDI neither spur nor retard economic growth of the countries when thresholds of either trade openness or exports are ignored. Considering thresholds for the FDI-economic growth relationship, we discover that FDI has a negative and statistically insignificant relationship with economic growth in Botswana when trade openness is less than the threshold value of $104.85 \%$. However, FDI has a negative and statistically significant relationship with economic growth above the threshold value of trade openness. The coefficient of FDI above trade openness threshold level indicates that a unit-percentage increase in FDI decreases economic growth by $0.451 \%$. Also, the relationship between FDI and economic growth is positive albeit not statistically significant below the exports threshold value of $55.06 \%$. On the contrary, a negative and statistically significant relationship exists when the threshold value of exports is surpassed. There is a reduction in economic growth by $1.773 \%$ as a result of a unit-percentage increase in FDI when exports threshold is exceeded. These findings demonstrate that FDI does not influence economic growth of Botswana in low regimes of trade openness and exports, but deters economic growth in high regimes of trade openness and exports. Thus, Bhagwati hypothesis does not hold true for Botswana.

For Cameroon, FDI has a positive and statistically insignificant relationship with economic growth below the trade openness threshold value of $49.321 \%$. However, the FDI-economic growth relationship, while still positive, becomes statistically significant when the threshold level of trade openness is exceeded. The coefficient of FDI above trade openness threshold indicates that a unit-percentage in FDI enhances economic growth by $1.353 \%$. The relationship between FDI and economic growth is positive and not statistically significant below and above the exports threshold value of $21.735 \%$. This finding indicates that the nature of relationship between FDI and economic growth is consistent at low and high regimes of exports. We show for Cameroon that FDI promotes economic growth in high regime of trade openness, but does not facilitate economic growth in low regime of trade openness. Thus, we offer evidence to validate Bhagwati hypothesis in Cameroon. Only exports is used to identify threshold for the FDI-economic growth relationship in Equatorial Guinea. The results show that the exports threshold estimate is $89.224 \%$. The relationship between FDI and economic growth is positive but not statistically significant below the threshold. Above the threshold, this relationship is negative and statistically significant. At any level exceeding the exports threshold, a unitpercentage increase in FDI causes economic growth to reduce by $0.734 \%$. We find that FDI fail to promote economic growth in Equatorial Guinea at high-exports regime; rather it becomes harmful to economic growth. It is therefore apparent that Bhagwati hypothesis is not valid for Equatorial Guinea. 
Table 2A: Threshold estimation effects

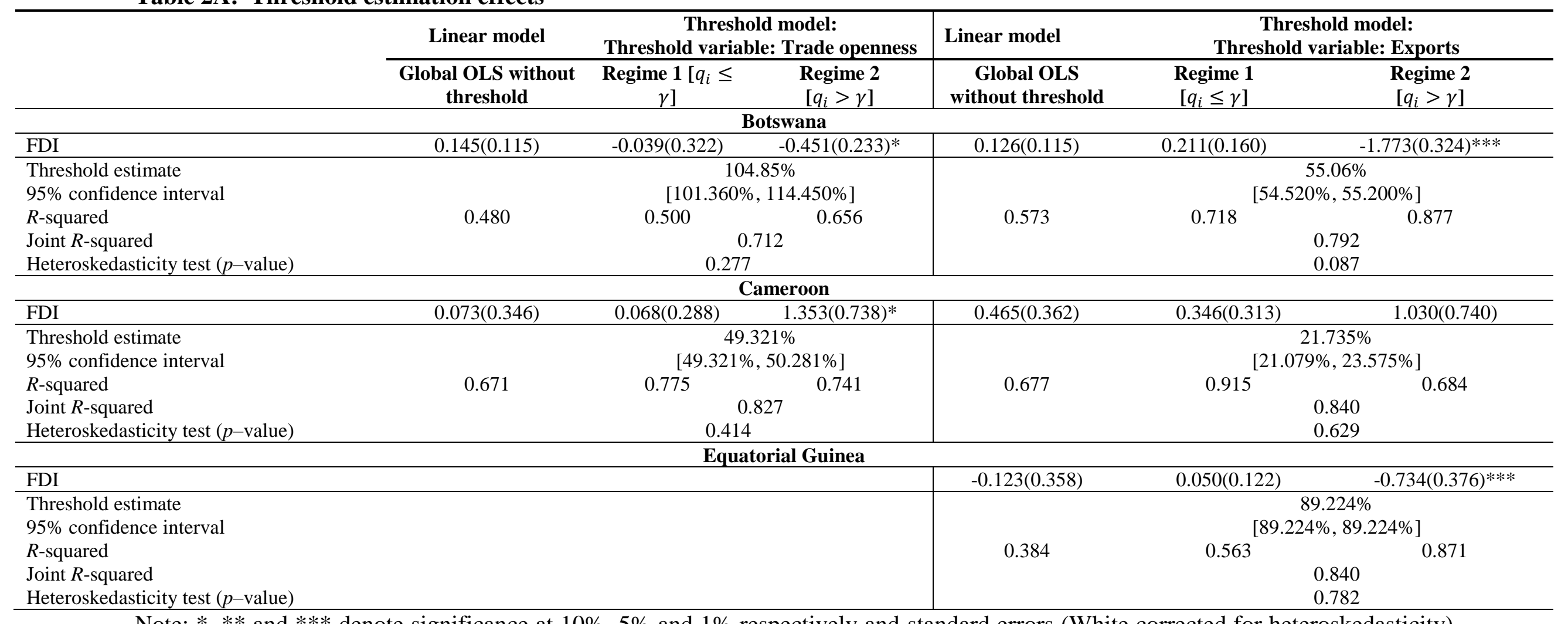

Note: $*, * *$ and $* * *$ denote significance at $10 \%, 5 \%$ and $1 \%$ respectively and standard errors (White corrected for heteroskedasticity) are placed in parentheses. 
Table 2B: Threshold estimation effects

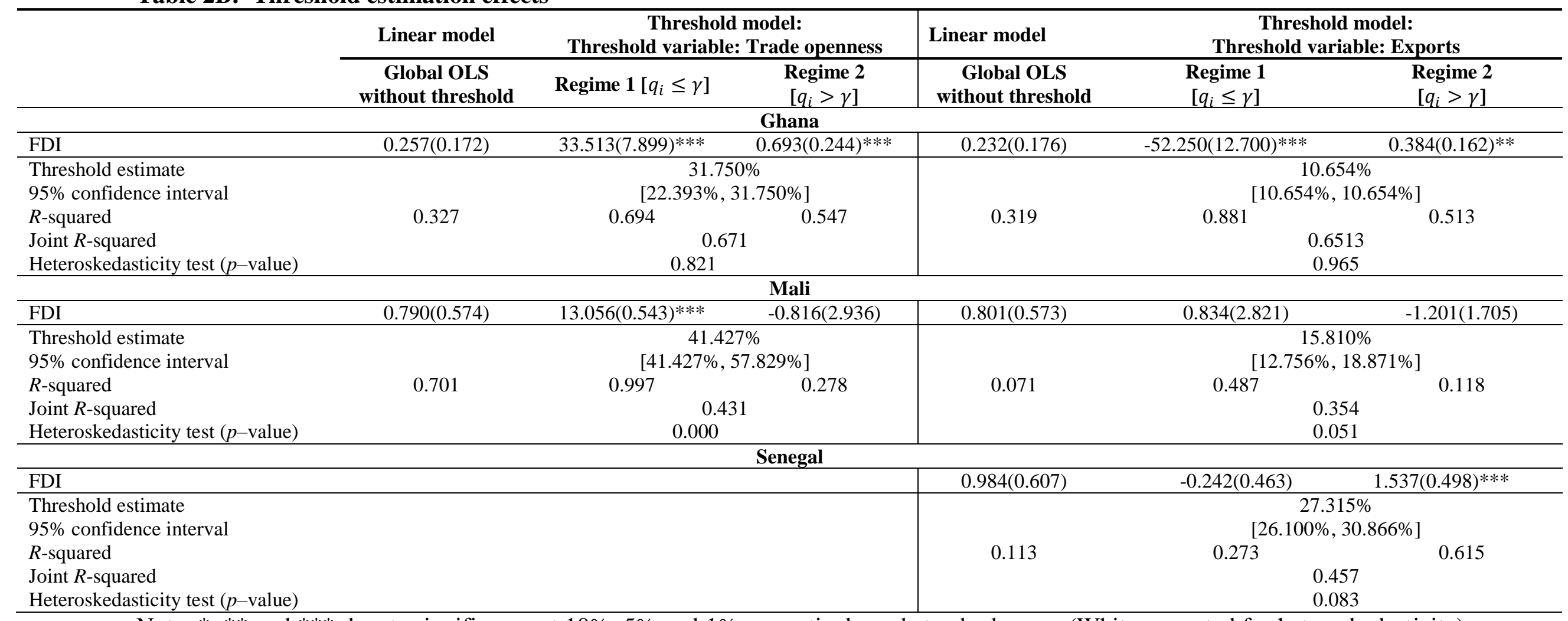

Note: $* * *$ and $* * *$ denote significance at $10 \%, 5 \%$ and $1 \%$ respectively and standard errors (White corrected for heteroskedasticity) are placed in parentheses 
Table 2C: Threshold estimation effects

\begin{tabular}{|c|c|c|c|c|c|c|}
\hline & \multirow{2}{*}{$\begin{array}{c}\text { Linear model } \\
\begin{array}{c}\text { Global OLS without } \\
\text { threshold }\end{array} \\
\end{array}$} & \multicolumn{2}{|c|}{$\begin{array}{c}\text { Threshold model: } \\
\text { Threshold variable: Trade openness }\end{array}$} & \multirow{2}{*}{$\begin{array}{c}\text { Linear model } \\
\text { Global OLS } \\
\text { without threshold } \\
\end{array}$} & \multicolumn{2}{|c|}{$\begin{array}{c}\text { Threshold model: } \\
\text { Threshold variable: Exports }\end{array}$} \\
\hline & & Regime $1\left[q_{i} \leq \gamma\right]$ & $\begin{array}{c}\text { Regime 2 } \\
{\left[q_{i}>\gamma\right]}\end{array}$ & & $\begin{array}{c}\text { Regime 1 } \\
{\left[q_{i} \leq \gamma\right]}\end{array}$ & $\begin{array}{c}\text { Regime } 2 \\
{\left[q_{i}>\gamma\right]}\end{array}$ \\
\hline \multicolumn{7}{|c|}{ South Africa } \\
\hline FDI & $0.335(0.293)$ & $1.039(0.303)^{* * *}$ & $-0.017(0.355)$ & & & \\
\hline Threshold estimate & \multicolumn{3}{|c|}{$48.890 \%$} & & & \\
\hline $95 \%$ confidence interval & \multicolumn{3}{|c|}{$[45.835 \%, 59.764 \%]$} & & & \\
\hline$R$-squared & 0.188 & 0.882 & 0.169 & & & \\
\hline Joint $R$-squared & \multirow{2}{*}{\multicolumn{3}{|c|}{$\begin{array}{l}0.479 \\
0.725\end{array}$}} & & & \\
\hline Heteroskedasticity test ( $p$-value) & & & & & & \\
\hline
\end{tabular}


Shifting attention to Ghana, the results show that the FDI-economic growth relationship is positive and statistically significant below and above the trade openness threshold value of $31.750 \%$. Below the threshold level of trade openness, the coefficient of FDI indicates that a unit-percentage increase in FDI increases economic growth by $33.513 \%$. When trade openness exceeds $31.750 \%$, a unit percentage rise in FDI boosts economic growth by a modicum percentage of $0.693 \%$. Using exports as the threshold variable, the results show that there is dissimilarity in the relationship between FDI and economic growth below and above the threshold level. The relationship is negative and statistically significant below the threshold level, but positive and statistically significant above the threshold. The FDI coefficient below exports threshold indicates that economic growth experiences a huge decline of $52.50 \%$ due to a unit-percentage increase in FDI. Conversely, above exports threshold, a unit-percentage increase in FDI stimulates economic growth by $0.384 \%$. The findings show, on one hand, that the FDI plays a growth-promoting role in Ghana at low regime of trade openness, although this role is reduced at high regime of trade openness. On the other hand, the findings reveal that FDI positively impact on economic growth in Ghana at regime of high exports only. On the basis of these findings, Bhagwati hypothesis is rejected for Ghana using trade openness as the threshold variable. However, we fail to reject the hypothesis when exports serve as the threshold variable. Thus, we provide divergent evidence which suggests that the validity of Bhagwati hypothesis in Ghana depends on the level of openness.

In Mali, a negative and statistically significant relationship subsists between FDI and economic growth when trade openness is lesser than the threshold value of $41.427 \%$. However, this relationship becomes positive but statistically insignificant above the threshold value. The coefficient of FDI in regime 1 of trade openness indicates that a unit-percentage increase in FDI leads to $13.056 \%$ increase in economic growth when trade openness is not beyond its threshold value. With exports as the threshold variable, the results demonstrate that no statistically significant relationship subsist between FDI and economic growth below and above the threshold value of $15.810 \%$. We establish that FDI hinders economic growth in Mali at low regime of trade openness, but economic growth is unaffected by FDI at high trade openness regime. We also show that FDI does not have significant implications for economic growth at low- and highexport regimes. Consequently, evidence to support Bhagwati hypothesis is non-existent for Mali.

In the case of Senegal, only exports act as the threshold variable. At level below the threshold of $27.315 \%$, FDI has a statistically significant negative relationship with economic growth. Above the threshold level, this relationship is altered and it turns to be positive and statistically significant. A unit-percentage rise in FDI fosters economic growth by $1.537 \%$ at levels higher than the exports threshold. Our findings indicate that the impact of FDI on economic growth in Senegal is not felt at low-exports regime; however, FDI promotes economic growth at highexports regime. This suggests that Bhagwati hypothesis can be upheld for Senegal. For South Africa, only trade openness is relied on as the threshold variable and it has a threshold value of $48.890 \%$. FDI has a positive and statistically significant relationship with economic growth below the threshold. Going beyond the threshold, the relationship between FDI and economic growth becomes negative and statistically insignificant. The coefficient of FDI indicates that a unit-percentage increase in FDI causes $1.039 \%$ increase in economic growth in regime 1 of trade openness, provided trade openness is below $48.890 \%$. These findings inform that FDI is only 
beneficial for economic growth in South Africa in low regime of trade openness, thus implying that South Africa does not follow the postulation of Bhagwati hypothesis.

\subsection{Concluding remarks}

Bhagwati hypothesis holds that the overall impact of FDI on economic growth is conditioned on countries' level of integration with the international market. This study re-examines this hypothesis by determining the impact of FDI on economic growth conditioned on countries level of openness in 17 selected SSA countries. By relying on a sample splitting technique while considering the different heterogeneous characteristics of each country, we document three key findings: First, there is evidence of complete Bhagwati hypothesis for three countries where both trade openness and exports mediate the relationship between FDI and economic growth. Second, there is also evidence of incomplete Bhagwati hypothesis for four countries given the measure of openness. Third, we do not find support for the hypothesis in majority of the countries. Thus, whether the level of openness mediates the relationship between FDI and economic growth depends on both the country characteristics and the indicator of openness. In order for countries with evidence of complete and incomplete Bhagwati hypothesis to enjoy the growth benefits of FDI, we imply from the threshold estimations for policy direction. It is imperative for Botswana, Ghana, Mali and South Africa to ensure that trade openness is kept below the threshold while Cameroon should maintain trade openness above the threshold. Similarly, exports should not be allowed to exceed the threshold in Botswana and Equatorial Guinea. However, in Ghana and Senegal, it would be beneficial to allow exports exceed the threshold. It is important for caution to be exercised in Ghana given the conflicting evidence.

\section{Disclosure statement}

The authors declare that there is no conflict of interest.

\section{Data availability statement}

The data used in this study are available on request. 


\section{References}

Acquah, M., A., \& Ibrahim, M. (2019). Foreign direct investment, economic growth and financial sector development in Africa. The Journal of Sustainable Finance and Investment, https://doi.org/10.1080/20430795.2019.1683504.

Adams, S., \& Opoku, E. E. O. (2015). Foreign direct investment, regulations and growth in subSaharan Africa. Economic Analysis and Policy, 47, 48-56.

Alagidede, P., Mensah, J. O., and Ibrahim, M., (2018). Optimal Fiscal Deficit Financing in a Constrained Fiscal Space in Ghana, African Development Review, 30(3), 291-303.

Aluko, O. A., \& Ibrahim, M., (2020a). On the Macroeconomic Determinants of Financial Institutions Development in sub-Saharan Africa, International Review of Economics, 67(1), 69-85.

Aluko, O. A.,\& Ibrahim, M. (2020b). Institutions and the financial development-economic growth nexus in sub-Saharan Africa. Economic Notes, 49(3), 1-16. https://doi.org/10.1111/ecno.12163

Asamoah, L. A., Mensah, E. K., \&Bondzie, E. A. (2019). Trade openness, FDI and economic growth in sub-Saharan Africa: do institutions matter? Transnational Corporations Review, 11(1), 65-79.

Atique, Z., Ahmad, M. H., Azhar, U., \& Khan, A. H. (2004). The impact of FDI on economic growth under foreign trade regimes: A case study of Pakistan. The Pakistan Development Review, 43(4), 707-718.

Balasubramanyam, V. N., Salisu, M., \& Sapsford, D. (1996). Foreign direct investment and growth in EP and IS countries. The Economic Journal, 106(434), 92-105.

Bhagwati, J. (1973). The theory of immiserizing growth: Further applications. In M. Connolly \& A. Swoboda (Eds.), International trade and money (pp. 45-54). Toronto: University of Toronto Press.

Bhagwati, J. (1978). Anatomy and consequences of exchange control regimes. USA: National Bureau of Economic Research.

Bouchoucha, N.,\&Yahyaoui, I., (2019). Foreign direct Investment and economic growth: The role of the governance, Economics Bulletin, 39(4), 2711-2725.

Hansen, B. E. (1996). Inference when a nuisance parameter is not identified under the Hypothesis, Econometrica, 64 (2), 413-430

Hansen, B. E., (2000). Sample splitting and threshold estimation, Econometrica, 68(3), 575-603.

Hoang, T. T., Wiboonchutikula, P., \&Tubtimtong, B. (2010). Does foreign direct investment promote economic growth in Vietnam?. ASEAN Economic Bulletin, 295-311.

Hsiao, F. S., \& Hsiao, M. C. W. (2006). FDI, exports, and GDP in East and Southeast AsiaPanel data versus time-series causality analyses. Journal of Asian Economics, 17(6), 10821106.

Iamsiraroj, S. (2016). The foreign direct investment-economic growth nexus. International Review of Economics \& Finance, 42, 116-133.

Ibrahim, M. (2018). Interactive effects of human capital in finance-economic growth nexus in sub-Saharan Africa. Journal of Economic Studies, 45(6), 1192-1210.

Ibrahim, M., \&Alagidede, P., (2017a). Financial Development, Growth Volatility and Information Asymmetry in sub-Saharan Africa: Does Law Matter? South African Journal of Economics, 85(4), 570-588. 
Ibrahim, M., \&Alagidede, P., (2017b). Financial Sector Development, Economic Volatility and Shocks in sub-Saharan Africa, Physica A, 484, 66-81.

Ibrahim, M., \&Alagidede, P., (2018). Effect of Financial Development on Economic Growth in sub-Saharan Africa, Journal of Policy Modeling, 40(6), 1104-1125.

Ibrahim, M., \&Sare, Y. A., (2018). Determinants of Financial Development in Africa: How robust is the Interactive Effect of Trade Openness and Human Capital? Economic Analysis and Policy, 60, 18-26.

Ibrahim, M., Ibrahim, O. A., \&Sare, Y. A., (2019). Networking for foreign direct investment in Africa: How important are ICT environment and financial sector development? Journal of Economic Integration, 34(2), 141-164.

Iyke, B. N. (2018). The real effect of currency misalignment on productivity growth: evidence from middle-income economies. Empirical Economics, 55(4), 1637-1659.

Kohpaiboon, A. (2003). Foreign trade regimes and the FDI-growth nexus: A case study of Thailand. The Journal of Development Studies, 40(2), 55-69.

Liu, X., Burridge, P., \& Sinclair, P. J. (2002). Relationships between economic growth, foreign direct investment and trade: evidence from China. Applied Economics, 34(11), 1433-1440.

Liu, X., Shu, C., \& Sinclair, P. (2009). Trade, foreign direct investment and economic growth in Asian economies. Applied Economics, 41(13), 1603-1612.

Mahembe, E. E., \& Odhiambo, N. M. (2016). Does foreign direct investment cause economic growth? A dynamic panel data analysis for SADC countries. International Journal of Emerging Markets, 11(3), 316-332.

Makki, S. S., \&Somwaru, A. (2004). Impact of foreign direct investment and trade on economic growth: Evidence from developing countries. American Journal of Agricultural Economics, 86(3), 795-801.

MIGA. (2015). MIGA Annual Report 2015. Retrieved from https://www.miga.org/documents/annual-report-2015.pdf

Musila, J. W., \&Yiheyis, Z. (2015). The impact of trade openness on growth: The case of Kenya. Journal of Policy Modeling, 37(2), 342-354.

Olawumi, A. D. (2019). Human Capital Development and Economic Growth in BRICS Countries: Controlling for Country Differences. Journal of Economics and Behavioral Studies, 11(4 (J)), 1-17.

Opoku, E. E. O., Ibrahim, M., \&Sare, Y. A., (2019). Foreign Direct Investment, Sectoral Effects and Economic Growth in Africa, International Economic Journal, 33(3), 473-492.

Osei, D. B., Sare, Y. A., \& Ibrahim, M., (2019). On the Determinants of Trade Openness in Low and Lower Middle-Income Countries in Africa: How Important is Economic Growth? Future Business Journal, https://doi.org/10.1186/s43093-019-0002-8.

Rani, R., \& Kumar, N. (2019). On the Causal Dynamics Between Economic Growth, Trade Openness and Gross Capital Formation: Evidence from BRICS Countries. Global Business Review, 20(3), 795-812.

Sakyi, D., \&Egyir, J. (2017). Effects of trade and FDI on economic growth in Africa: an empirical investigation. Transnational Corporations Review, 9(2), 66-87.

Sakyi, D., Commodore, R., \& Opoku, E. E. O. (2015). Foreign direct investment, trade openness and economic growth in Ghana: An empirical investigation. Journal of African Business, 16(1-2), 1-15.

Soumaré, I. (2015). Does FDI improve economic development in North African countries?. Applied Economics, 47(51), 5510-5533. 
Sultanuzzaman, M. R., Fan, H., Akash, M., Wang, B., \&Shakij, U. S. M. (2018). The role of FDI inflows and export on economic growth in Sri Lanka: An ARDL approach. Cogent Economics \& Finance, 6(1), 1518116.

Zahonogo, P. (2016). Trade and economic growth in developing countries: Evidence from subSaharan Africa. Journal of African Trade, 3(1-2), 41-56.

Zekarias, S. M. (2016). The impact of foreign direct investment (FDI) on economic growth in Eastern Africa: Evidence from panel data analysis. Applied Economics and Finance, 3(1), 145-160.

Zhang, K. H. (2001). Does foreign direct investment promote economic growth? Evidence from East Asia and Latin America. Contemporary Economic Policy, 19(2), 175-185. 


\section{Appendix}

Fig. 1: Confidence interval for trade openness threshold for Botswana

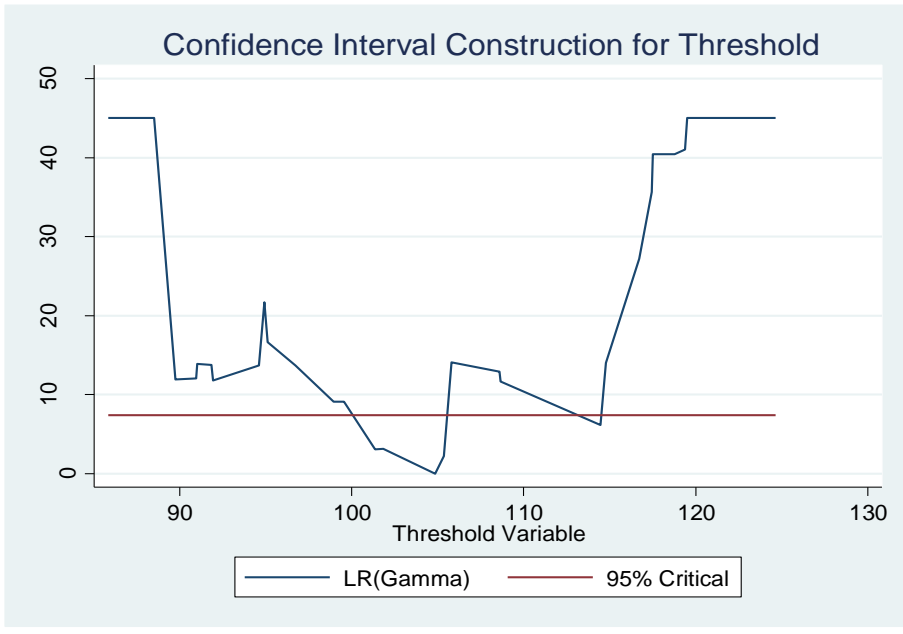

Fig. 2: Confidence interval for exports threshold for Botswana

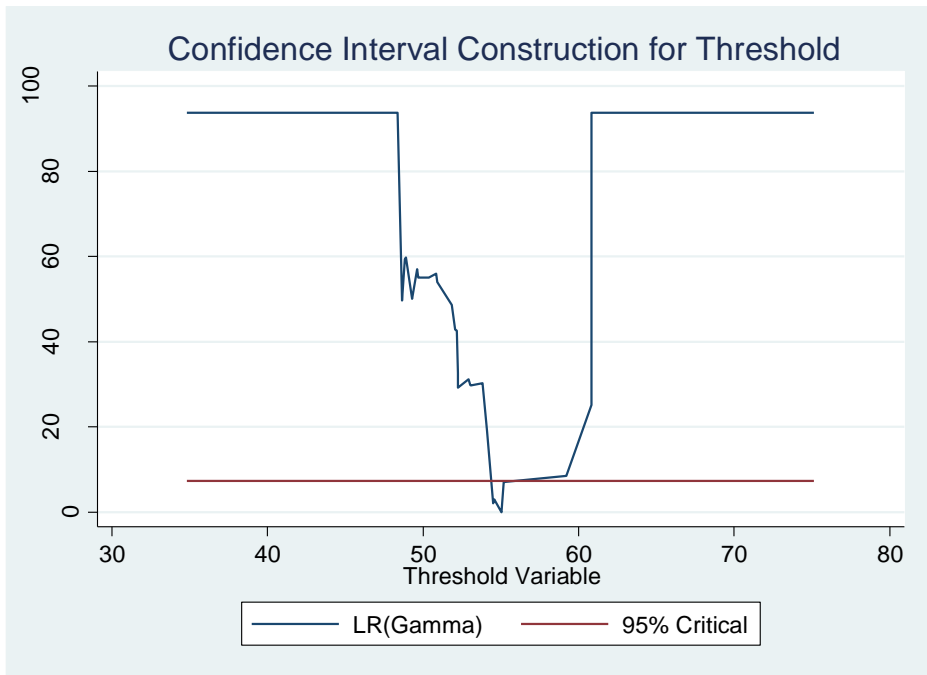


Fig. 3: Confidence interval for trade openness threshold for Cameroon

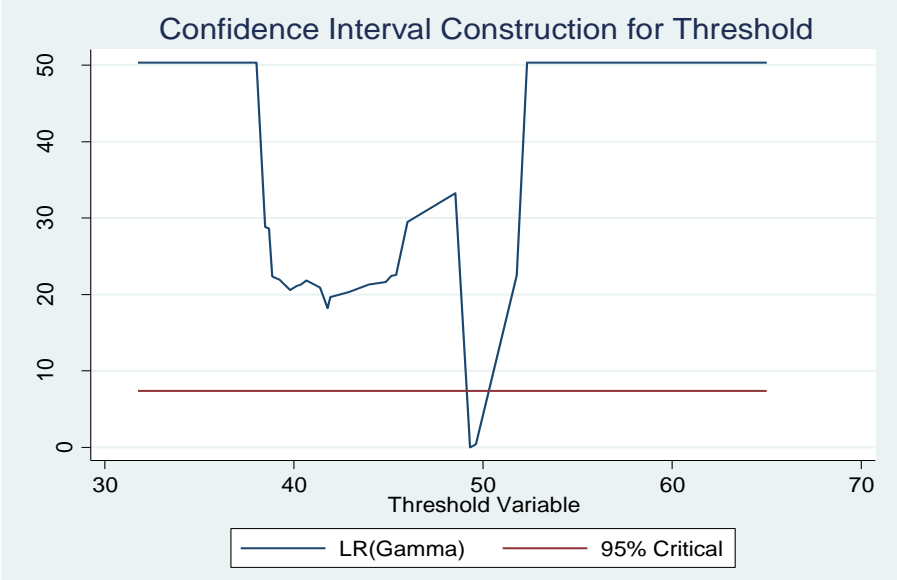

Fig. 4: Confidence interval for exports threshold for Cameroon

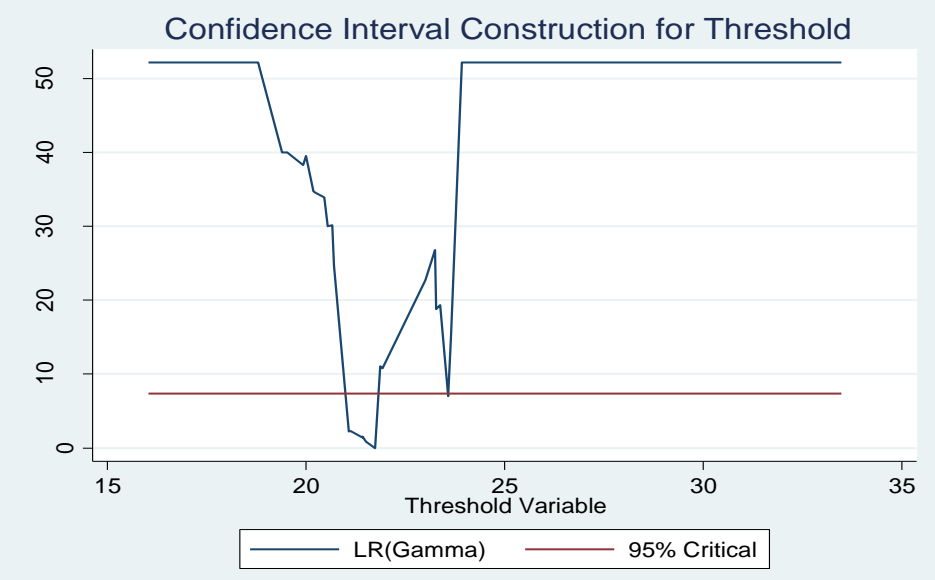


Fig. 5: Confidence interval for exports threshold for Equatorial Guinea

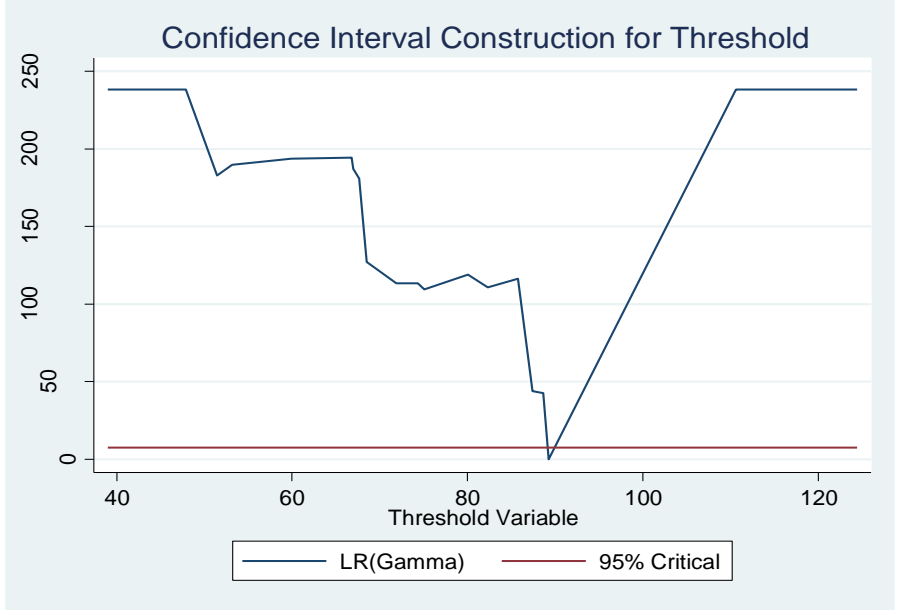

Fig. 6: Confidence interval for trade openness threshold for Ghana

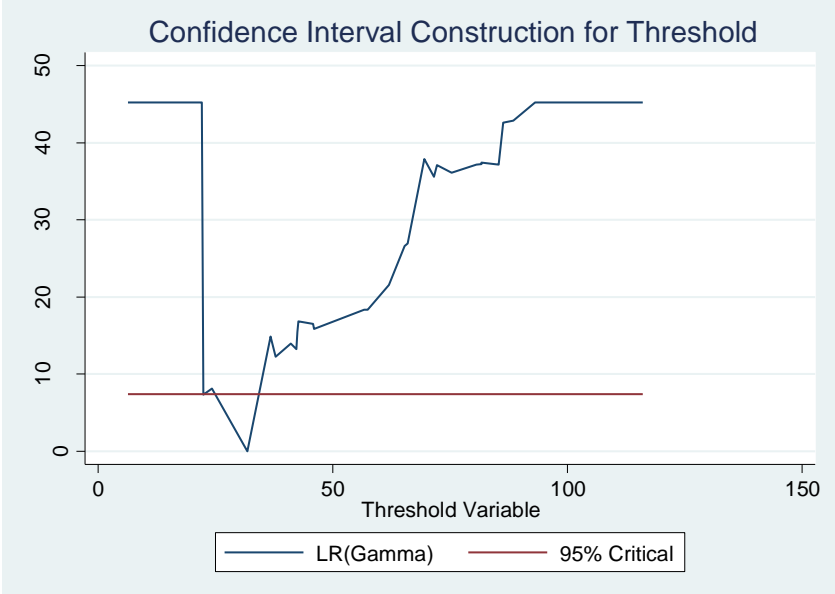

Fig. 7: Confidence interval for exports threshold for Ghana

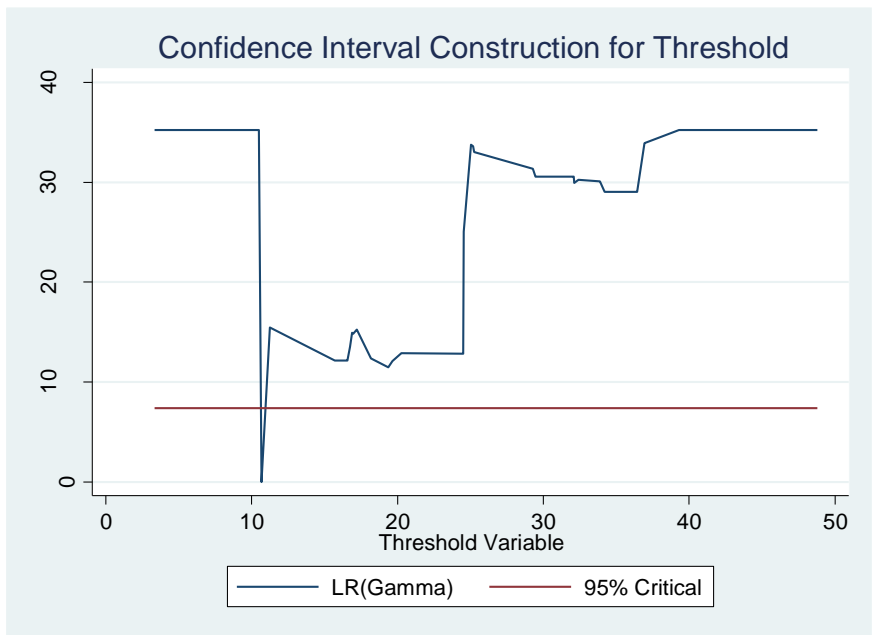


Fig. 8: Confidence interval for trade openness threshold for Mali

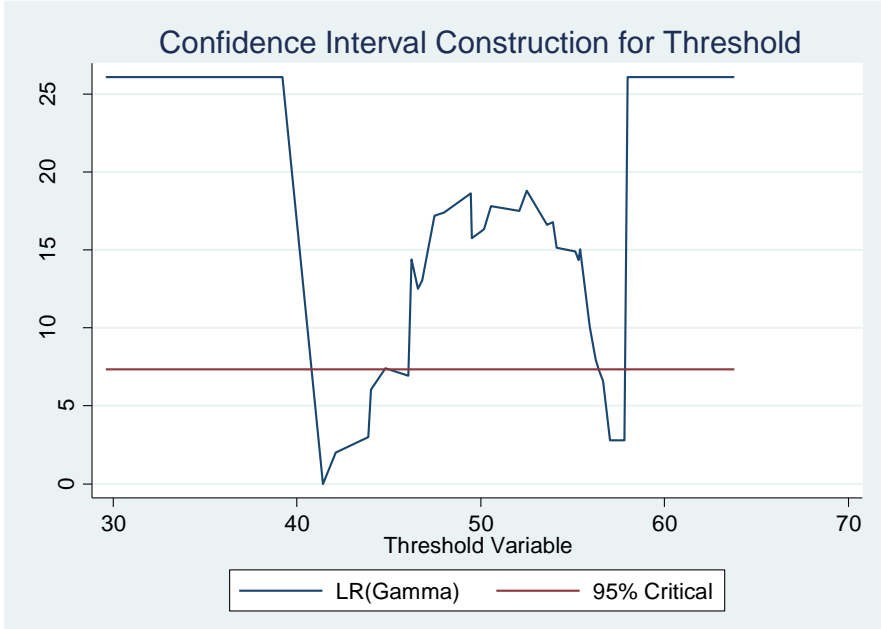

Fig. 9: Confidence interval for exports threshold for Mali

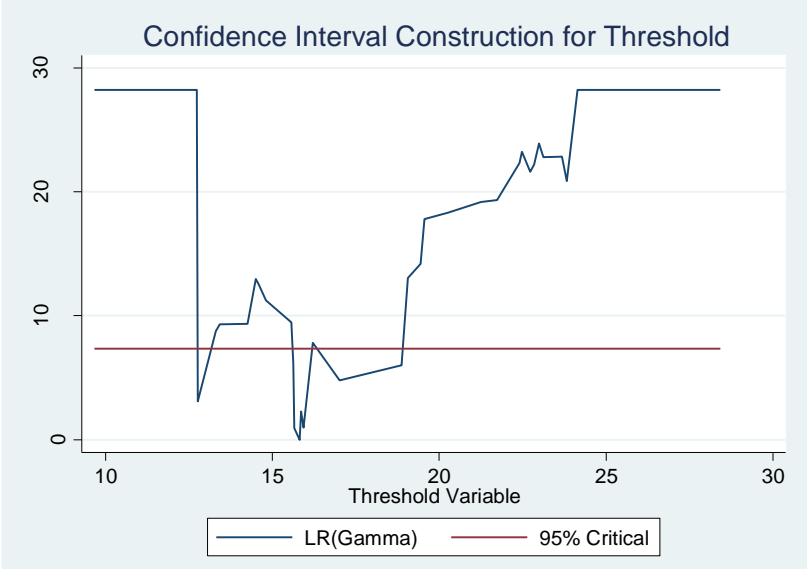

Fig. 10: Confidence interval for exports threshold for Senegal

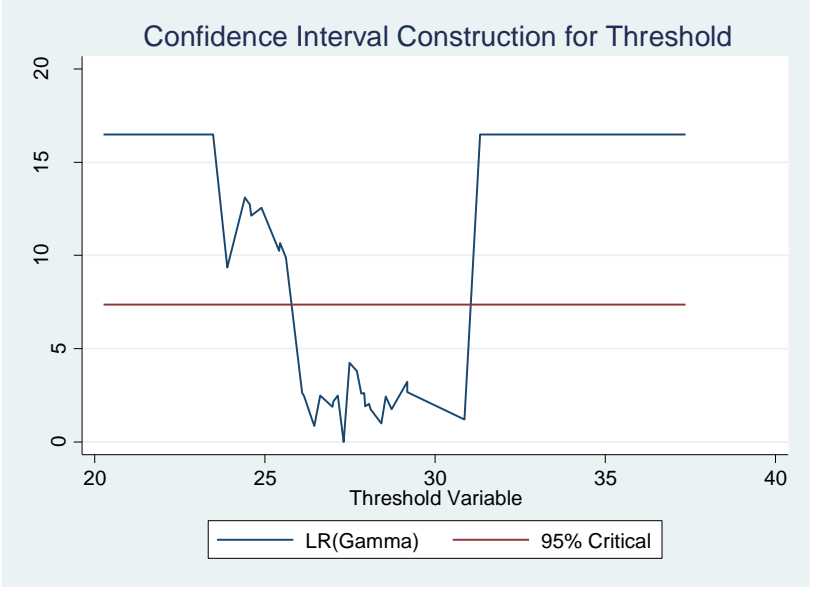


Fig. 11: Confidence interval for trade openness threshold for South Africa

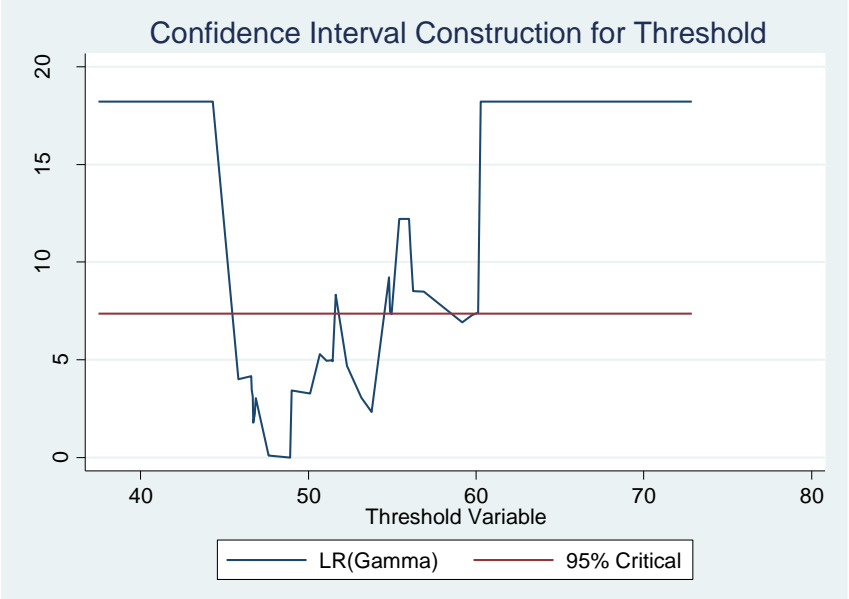

